\title{
Road Safety Education: A \\ Paradoxical State for Children \\ in a Rural Primary School in \\ South Africa
}

\author{
Ina JC Joubert and William J Fraser
}

University of Pretoria, South Africa

\section{Mpoye L Sentsho}

Road Safety Management, South Africa

\begin{abstract}
The study explores the response of rural primary school children to road safety education programmes. In this qualitative research project, we employed an interpretivist paradigm to investigate and understand children's responses to road safety education in one school in the Moloto Village, Mpumalanga Province, South Africa. Drawing on various participatory activities done by the child participants, as well as nonparticipant observation by the researchers through 'photo voice', the researchers posit their findings. The key finding is that the children theoretically know what to do when using the road as pedestrians but that they do not apply road safety rules as the community's unsafe road use behaviour undermines all road safety skills the children have learnt at school. The paradox between what the literature on road safety education prescribes and what the national curriculum of South Africa promotes regarding road safety, and what the children apply in their daily lives, is apparent and noteworthy.
\end{abstract}

\section{Keywords}

Primary school children, road safety education, rural road environment, unsafe road use

\section{Introduction}

Road accidents are a major and growing cause of injury and death to children in developing countries like South Africa (Roadsafe, 2006; Road Safety Manual, 2003; Zeedyk et al., 2001). Many of these accidents involve child pedestrians. A Global Road Safety Partnership (GRSP) paper (2001: 2) titled 'Road Safety Education: Saving Young Lives and Limbs', asserts that twice as many pedestrians are killed in road accidents in developing countries as in European countries and

\section{Corresponding author:}

Ina JC Joubert, Department of Early Childhood Education, University of Pretoria (Groenkloof campus), Pretoria, 0002 , South Africa.

Email: ina.joubert@up.ac.za 
the United States of America (USA). The paper further states that a high proportion of these accidents involve young children. The grim scenario of children of school-going age being fatally injured is also reported by the Danish Road Safety Commission (2000). Almost two decades ago, Thomson et al. (1996) stated that, with regard to children, the problem was so severe that child pedestrian accidents were widely regarded as the most serious of all health risks facing children in developing countries.

In order to rectify this situation, educational measures have been advocated over many years as a means of teaching children how to cope with traffic in developed countries such as the USA and countries in Europe. Substantial resources have been devoted to developing and providing road safety education in these countries (Guldbrandsson and Bremberg, 2004; Jacobs and Aeron-Thomas, 2000; Odero, 2004). However, there seems to be a widespread view in the aforementioned countries that education on road safety has not achieved as much as had been hoped for and that there may even be limits to what could be achieved through education. This might shift the emphasis away from education towards engineering or urban planning measures aimed at creating an intrinsically safer environment in which the need for education might be reduced or even eliminated (Forjuoh, 2003; Muhlrad, 1998: 118-125; Ribbens, 2002; Zeedyk et al., 2001). In South Africa and other developing countries, engineering interventions are extremely expensive. Therefore, despite concerns raised about the constructive contribution of education to road safety in developed countries, education is the only feasible intervention for curbing the deaths of pedestrians, especially children, on the roads of South Africa (Department of Transport, 2001).

While examining the global phenomenon of road safety, we realized that there is in the international and national contexts an apparent lack of recent empirical research on how education for young children can contribute to their road safety. Furthermore, there is a lack of reliable information about the effectiveness of road safety education in rural areas of South Africa such as in the Moloto area in the province of Mpumalanga. Additionally, children's conceptualization of road safety remains poorly understood (Benjamin and Schwebel, 2007). Our study is therefore an attempt to better understand children's conceptualization of road safety knowledge and skills which may contribute to the existing knowledge on road safety education.

\section{Road Safety in the Global and South African Contexts}

Worldwide, the road safety problem is daunting. Globally, the epidemiology of road traffic deaths shows that traffic deaths account for almost $2 \%$ of all deaths among children as the road traffic death rate among children is 10.7 per 100,000 population (Commission for Global Road Safety: Fédération Internationale De L'automobile (FIA) Foundation, 2006). In many Asian, African and Middle Eastern countries, between $40 \%$ and $50 \%$ of people who are killed on the roads through traffic accidents are pedestrians, and $20 \%$ of those pedestrians are children. In the African region the death rate is $19.9 \%$ per 100,000 population (GRSP, 2003: 8). In South Africa, $40 \%$ of the total number of 12,000 people who die on the roads each year are pedestrians, of which $10 \%$ are children (US Department of Transportation, 2004). This costs the country over R36 billion annually (Cape Argus, 2004; Department of Transport, 2001).

Table 1 illustrates that, despite all the efforts to reduce the number of deaths of road users either as pedestrians or drivers, fatal crashes and deaths on the roads increase exponentially every year (Cape Times, 2004). In addition, Table 1 portrays the lack of recent statistics as this table was the only available source on these figures. 
Table I. Number of fatal crashes and fatalities on South African roads 200I-2004 (Road Traffic Management Corporation, 2005).

Annual number of fatal crashes and fatalities in South Africa

\begin{tabular}{lcccc}
\hline Year & Fatal crashes & \% change & Fatalities & \% change \\
\hline 2001 & 8,802 & & 11.201 & 8.90 \\
2002 & 9,973 & 13.30 & 12.198 & 1.23 \\
2003 & 10,246 & 2.74 & 12.348 & 2.92 \\
2004 & 10,523 & 2.70 & 12.709 & \\
\hline
\end{tabular}

A possible reason for the high percentage of child deaths as pedestrians could be the fact that road safety is a political and socio-economic issue (Forjuoh, 2003). According to the World Health Organization (2004), road safety is a phenomenon of enormous human extent with massive economic proportions. It is also an issue of vast social proportions affecting issues of equity. Road safety especially affects poor people, as some $93 \%$ of child road deaths occur in lowincome and middle-income countries. People from low-income groups are at great risk from road crashes, as they are more likely to be pedestrians or public transport passengers (Commission for Global Safety: FIA Foundation, 2006; Danish Road Safety Commission, 2000; Jacobs and AeronThomas, 2000; McComas et al., 2002; Road Safety Manual, 2003; Sukhai, 2003; World Health Organization, 2004).

About 12.47 million people (13.4\% of the South African population) live in rural areas (Presidency, 2001). Many of the adults in the rural areas cannot afford their own vehicles so they are forced to be pedestrians, the group most vulnerable to road traffic accidents. In addition, the majority of pedestrians, including children, live along the highways that go through informal settlements in rural areas. People gravitate towards the highways in search of a means of earning a living. Many hawkers sell their products along the highways and this leads to the establishment of settlements near these people's source of income, namely the highways. The problem manifests itself along most major routes in South Africa. The Moloto road is one such road, as it carries heavy volumes of traffic, particularly in the mornings and in the afternoons when commuters travel to the Tshwane Metropolis. Other routes are the N4 east at the Clewer interchange in the Mpumalanga Province, the N4 west near Majakaneng settlement in the northwest, the N1 north in Hammanskraal, the N1 south near the Grasmere tollgate and the N28 near Diepsloot in Gauteng (Ribbens, 2002).

South Africa invests millions of rand in road safety measures in an attempt to arrest the situation on a national level. One such ongoing strategy is the Arrive Alive Campaign which was launched in 2001 (Road Traffic Management Corporation [RTMC], 2005). Arrive Alive is the Department of Transport's road safety campaign, and its purpose is to reduce deaths and serious injuries on the roads of South Africa by means of a multi-disciplinary approach to road safety. This approach includes communication (education, advertising and public relations) together with enforcement to reduce the offence rate for primary offences (speed, alcohol and seat belts), as well as general law enforcement, in an effort to change behaviour and attitudes (RTMC, 2005). The campaign alone spends R50 million sponsored by the Road Accident Fund (RAF) on road safety annually (National Department of Transport, 2006).

The first leg of the campaign was the implementation of mass communication of road safety messages aimed at educating and enhancing awareness through television, radio and the press. 
Research showed that this campaign reached many road users including pedestrians (RTMC, 2005). The second leg of the campaign was the introduction of road safety competencies in schools as part of the mainstream curriculum. This was an interdepartmental effort between the then Department of Education and Department of Transport. Although this innovation has stabilized the situation, it has not eliminated fatal child injuries on South African roads (Herald Reporter, 2004). Against this background, our research question was: what is the response of rural primary school children to road safety education programmes?

\section{Conceptual Platforms of the Study}

Road safety education and young children's conceptualization thereof are the conceptual platforms of this study. When describing these concepts supporting theories are provided. We describe the significance of each concept in this section.

\section{Road Safety Education}

Wittink (1998) regards road safety education as the teaching of skills, knowledge, understanding and behavioural patterns to enable road users to prevent accidents. It takes place at primary and secondary schools, driving schools and driving courses. He cautions, however, that road users learn most by the practical application of the theory. Therefore education needs to provide a basis for the learning processes related to traffic and road use. Safe road use behaviour cannot be learnt without practice. If education is not adjusted to the learning process of road users, it cannot be very effective.

A study by Davis and Quimby (2003: 1-14) in the United Kingdom (UK) established that professionals in the fields of education and communication have recognized the need for a holistic educational approach to influence the behaviour of community members, especially the young. Resulting from this research, road safety education is provided to children from preschool to secondary school by the North Lanarkshire Council. Through the Child Development and Road Safety Research Programme (UK Department for Transport, 2007) the development of pedestrian skills is taught to 4-11-year-old children in order to improve safe pedestrian behaviour.

The Swedish school curriculum aims at teaching traffic knowledge and skills from an early age and throughout the school phases. The stated aims of this curriculum are that, at all phases, the road safety knowledge gained by children should be regularly applied in a realistic traffic environment (Muhlrad, 1998: 233; Ryhammar, 1988: 14).

In the USA, the state of Oregon's Driver and Traffic Safety Education (DTSE) curriculum aims to provide learning experiences which equip students with the required knowledge, thought processes, insights, and motivations so that they may become safe and efficient drivers. These qualities are instilled through classroom and laboratory learning activities which are guided by measurable objectives. The curriculum stipulates that the best results are obtained when children's experiences in the classroom and behind the wheel are closely correlated in philosophy, content, methods, and scheduling (see also Muhlrad and Wittink, 1998: 246-256; US Department of Transportation, 2004: 115-116). In Oregon, road safety education is reported to be effective as the local level of government is taking the initiative and organizing the programmes.

From an African perspective, the literature indicates that much attention has been given by both national organizations and national donors to inculcating safe road use behaviour in children. Most 
of the efforts have focused on the formal education system with the development of materials and the inclusion of traffic safety in the school curriculum. Progress has been made in Ghana, where the Department for International Development has developed educational materials that have been employed by the educational authorities of Uganda (Accra Declaration Ministerial Round Table, 2007; World Bank Group, 2002). Yet the literature also revealed that, in the African context, road safety is more on the conceptualization level and less on the implementation level in communities and schools. It would appear that there is a need to move from conceptualization to implementation (Forjuoh, 2003; McComas et al., 2002; Odero, 2004; Ribbens, 2002; Zeedyk et al., 2001). Understanding how 10-14-year-old children conceptualize road safety education might assist in its implementation.

With the advent of the South African democracy in 1994, road safety education became part of the mainstream curriculum in South African schools, within the Life Orientation learning area (Department of Education, 2002). However, only one assessment standard is directly related to road safety education: 'List and explain traffic rules relevant to road users'. As language is always integrated with any learning, an assessment standard of learning outcome two of the Home Language learning area could be related to road safety education: 'Reads for information; follows instructions, recipes, maps and plans'. Although the inclusion of road safety in the national curriculum was an important addition, the content related to road safety lacks depth and therefore needs examination when exploring the response of 10-14-year-old children to road safety education in a rural environment.

\section{Children and Road Safety Education}

Literature on road safety education indicates that developed countries address the aspects of road safety knowledge in their curricula related to the development of the child. Consequently, this section explores first who the child participants of the study were, as we had to ask ourselves the following questions: who are the children in the rural environment? Can we rely on their responses, considering their young age? How do young children learn road safety, especially in a rural environment? Can their responses inform road safety education programmes? We realized that we needed to consider aspects such as their human rights, their developmental phase and learning theories relevant to the child's learning of road safety education.

Although the United Nations Convention on the Rights of the Child, Article 1, defines a child as a person below the age of 18 years (World Health Organization, 2004), we focused on the children in the intermediate phase of the primary school (the age group 10-14 years old) in the rural setting of Moloto Village. One reason for the emphasis on this age group was our consideration that these children are arguably more mature than very young children (Christie et al., 2004). Another reason was the fact that they mostly go to school unaccompanied by parents or adults as community members regard them as responsible (information revealed when talking to a parent in this community). However, the children in this rural milieu are exposed to hazards and risks as they walk and play on the roads in their immediate environment. This exposure makes them particularly vulnerable in the traffic context (World Health Organization, 2004).

Children's rights to a safe road environment are proclaimed by the United Nations Convention on the Rights of the Child (1989). The South African Constitution (Republic of South Africa, 1996) incorporates the Bill of Rights, which assures the right to safety and dignity for every individual. By adopting these universal rights as an instrument, civil society is able to demand safer products, safer living conditions and safer environments (Monson et al., 2006: 32). Although the right to a life safe from devastating injuries such as road accidents may seem implicit in the right to life, 
decision-makers and the public at large have yet to use this right to influence policy in this regard (Mohan, 2003).

When educating young children about road safety, their developmental level should be considered. During the intermediate phase the typical 10-14-year-old child grows into a capable young person who has mastered language, is able to deal with abstractions, solves problems systematically, can think and reason with some sophistication, has a distinctive personality, and mostly socializes naturally with others (Child Development, 2009; Mayer, 1987: 19-22; Slavin, 2002). These abilities are an indication that this age group could become safe road users, as learning road safety is based on the assumption that learners should be able to make critical decisions. During individual interviews with participants it was obvious that the children of our case study were eager to learn, an aspect which we considered positive for learning road safety skills.

What then are the knowledge and skills related to road safety that this age group could be expected to internalize? A report by the GRSP (2001) states that children from age eight to 12 should master the following learning outcomes or competencies:

- Identify and recommend safe places to play to smaller children.

- Understand the need to be seen (visibility) near and in traffic and judge the hazards of stationary vehicles and how to play or cross the road near them.

- Understand traffic lights, road signs, road markings and signals given by drivers and the police.

- Understand the concept of differing by observing traffic, know when and how to summon help in an emergency.

- Understand which road signs must be obeyed, which are warning signs and which provide information.

- Understand about visibility, complicity, adverse weather, vehicle control and braking.

- Be made aware that traffic rules are not always observed by other road users.

- Understand needs of special groups - the very young, the old and disabled.

- Understand problems of alcohol, drugs and fatigue in relation to road accidents.

- Understand immediate and long-term consequences of road accidents.

- Be aware of the importance of planning safe school routes when changing school.

- Understand problems caused by domestic and wild animals near roads.

- Set a good example to other children.

Literature indicates several 'learning theories' applicable for this research project such as the maturationist theory promoted by Gesell (in Hunt, 1969). For the purpose of this study we identified the behaviourist and the constructivist theory as the most relevant 'learning theories' (Hurlock, 1981; Schunk, 2012). When discussing each theory, we elaborate on its possible application.

According to behaviourists, learning is a reasonably enduring change in observable behaviour that occurs as a result of experience (Eggen and Kauchak, 2001; Slavin, 2002). The emphasis is thus on the acquisition of new behaviours via the imitation of actions modelled by others. Many road safety programmes like those implemented in the Netherlands and the UK were based on the principles of behaviourism and were successful. However, a major weakness of this learning theory could be the immense emphasis on the behaviour of people, including adults and children. Another weakness seems to be the dependence of children on other people, like teachers and parents, for information rather than seeking the information themselves (Department for Transport, 
2006). Thus behaviourism could undermine the child's metacognition when learning about road safety.

The second theory is the constructivist perspective of readiness and development as advanced by theorists such as Piaget, Montessori and Vygotsky (Bergin and Bergin, 2012; Glover and Bruning, 1990; Mayer, 1987; Slavin, 2002). Although their work varies greatly, these theorists are consistent in their belief that learning and development occur when young children interact with the environment and people around them (Campbell, 1997; Hunt, 1969; Schunk, 1991: 236-237). The essence of constructivist learning theory is that children construct, discover and transform complex information when making the information their own. In addition, children constantly examine new information against old rules and then revise the information when it is no longer applicable. This view has profound implications for teaching road safety, as it suggests a far more active role for children in their own learning than is typical in the majority of classrooms (Slavin, 2002: 225).

\section{Research Design and Methodology}

The data presented in this article is derived from a larger research project, where we employed a case study. The unit of analysis was one school in the Moloto Village in the Nkangala district in the province of Mpumalanga, South Africa. We selected this specific case purposefully (Merriam, 1998).With this case study we aimed to investigate the response of 10-14-year-old children to road safety education as they were living in a specific rural environment, where numerous fatal road accidents frequently occur on the Moloto road. Many of these accidents involve young children, as the Moloto road is situated near the school. The frequent accidents on the Moloto road are widely reported on local radio stations and in newspapers. Matipa (2012) identified this road as one of the most dangerous roads in the Gauteng province. As a result of the horrific accidents on this road it is called the 'road of death' by the local people. The children of our case study spoke Sepedi but were conversant with English to the extent that they were able to express themselves in English. They were divided in to four class groups according to their ages and referred to as the intermediate phase learners. Although the generalization of research results derived from this case study was an anticipated constraint (Denzin and Lincoln, 2000: 439), we provided an in-depth description of this rural environment for possible transferability to other contexts (Seale, 1999).

As interpretivists, we claim an approach to enquiry that was qualitative and subjective in nature (Merriam, 1998: 6). We assumed that young children's subjective experiences and understandings were real and should be taken seriously by adults. Our stance is contradictory to that of many communities where young children are regarded as insignificant citizens in civil society (Robinson and Kellet, 2004). We documented the voices of the children through their engagement in activities and discussions in an attempt to come to some understanding about the phenomenon of children and road safety education.

We used a variety of data collection instruments to obtain rich data in our attempt to answer our research question (May, 1997). Table 2 provides a summary of the methods and instruments that were used for data collection as well as the data capturing method.

The constructivist grounded theory analysis method as described by Charmaz (2000) was employed to investigate the data and to construct meaning. Constructivist grounded theory analysis assisted us in sensitizing concepts from different perspectives. Concepts emerged in themes and relevant categories, which we chose for their usefulness in an attempt to answer our research questions (Braun and Clarke, 2006: 78). 
Table 2. Data collection and data capturing methods.

\begin{tabular}{|c|c|c|c|c|}
\hline $\begin{array}{l}\text { Method of data } \\
\text { collection }\end{array}$ & Type & $\begin{array}{l}\text { Instruments } \\
\text { assisting data } \\
\text { collection }\end{array}$ & Prompt & $\begin{array}{l}\text { Data capturing } \\
\text { method:Textual } \\
\text { data }\end{array}$ \\
\hline $\begin{array}{l}\text { Observation } \\
\text { by using 'photo } \\
\text { voice'(Olivier, } \\
\text { Wood and De } \\
\text { Lange, 2009) }\end{array}$ & $\begin{array}{l}\text { Non-participant } \\
\text { observation by } \\
\text { researchers }\end{array}$ & $\begin{array}{l}\text { Observations with } \\
\text { digital camera }\end{array}$ & $\begin{array}{l}\text { None. Used 'natural } \\
\text { field setting'. Photos } \\
\text { were taken from } \\
\text { the local road } \\
\text { environment }\end{array}$ & $\begin{array}{l}\text { Photos. } \\
\text { Researchers' field } \\
\text { notes }\end{array}$ \\
\hline \multirow[t]{3}{*}{$\begin{array}{l}\text { Focused } \\
\text { interviews } \\
\text { (Adendorff, 2004) }\end{array}$} & $\begin{array}{l}\text { Individual } \\
\text { interviews with } \\
\text { I0-I4-year-old } \\
\text { children (Leedy and } \\
\text { Ormrod, 200I) }\end{array}$ & $\begin{array}{l}\text { Semi-structured } \\
\text { interview } \\
\text { schedule, tape } \\
\text { recorder }\end{array}$ & $\begin{array}{l}\text { Assurance that } \\
\text { learners should feel } \\
\text { free to respond } \\
\text { to questions, for } \\
\text { example on their } \\
\text { road use behaviour } \\
\text { and knowledge }\end{array}$ & Transcriptions \\
\hline & $\begin{array}{l}\text { Group interviews } \\
\text { (McMillan and } \\
\text { Schumacher, 2002) }\end{array}$ & $\begin{array}{l}\text { Drawings on large } \\
\text { sheets of used } \\
\text { paper. Researchers } \\
\text { interviewed them } \\
\text { on their drawings } \\
\text { and made notes }\end{array}$ & $\begin{array}{l}\text { Children in each } \\
\text { class given a task to } \\
\text { draw (individual or } \\
\text { in pairs) the Moloto } \\
\text { road with all the } \\
\text { aspects that they } \\
\text { would like to see on } \\
\text { the road to ensure } \\
\text { road safety }\end{array}$ & $\begin{array}{l}\text { Drawings with } \\
\text { notes written by } \\
\text { the researchers } \\
\text { at the back of the } \\
\text { drawings }\end{array}$ \\
\hline & & $\begin{array}{l}\text { Written messages } \\
\text { on A4 paper }\end{array}$ & $\begin{array}{l}\text { Children in each } \\
\text { class were asked to } \\
\text { write road safety } \\
\text { messages for their } \\
\text { community }\end{array}$ & $\begin{array}{l}\text { Written messages } \\
\text { and notes written } \\
\text { by the researchers } \\
\text { at the back of the } \\
\text { messages }\end{array}$ \\
\hline
\end{tabular}

\section{Research Findings and Discussion}

The 10-14-year-old children's understandings of road safety education emerged explicitly through four distinctive themes. We present the themes in the order of prominence. The themes are integrated and in many cases difficult to distinguish from one another. The following themes are discussed:

- Children's development of pedestrian skills.

- Children's construction of road safety knowledge.

- Children's attitudes to road safety and their value of life.

- Children being influenced by an unsafe road environment.

In the following section we explore the children's expressions against the conceptual platforms as described earlier. We commence with the first theme and provide evidence for its appearances.

\section{Development of Pedestrian Skills}

Pedestrian skills are important for children as they are exposed to traffic when they go to school or returning back home. Teaching of pedestrian skills to children is therefore critical. The data 
indicated that the children developed pedestrian skills to a certain extent. During the individual interviews they indicated what was required of them to ensure their safety before they crossed the road. Many indicated that they understood the basic rule that they should observe before crossing the road. The rule is: Look right - look left and look right again before you cross. The children's expressions are given verbatim.

I stop, look both sides and then I cross. (Child participant 1 [P1])

I look left and right and runs across the road. (P2)

I look left and right and right again then I cross. (P3)

The basic principle of crossing the road is understood, although to varying degrees. The correct procedure to follow would be: Look right, look left, look right again and then walk across the road. On the basic level, the child participants knew that they had to stop and look in both directions of the road to assess whether there was danger in the form of oncoming traffic before crossing. Through the individual interviews it became apparent that this was what they learnt in the classroom.

However, none of them provided an explanation as to why they were supposed to look right twice. As traffic keeps to the left of the road in South Africa, vehicles that pose immediate danger are those coming from the right-hand side of the pedestrian when crossing the road. A disturbing behaviour is that a few children stated that they had to run in order to be safe when crossing the street. To them, running fast meant avoiding the danger by crossing fast and quickly. Running across the road is not a safe behaviour or practice at all. If they fell, the oncoming vehicle would injure them, perhaps fatally. Another disturbing trend in the theme of developing pedestrian skills is that, in their task of writing road safety messages, most messages were aimed at drivers of vehicles and not at pedestrians. They thought that if drivers were to act according to their messages, then the problem of pedestrian accidents would be ameliorated.

\section{Construction of Road Safety Knowledge}

Children's construction of road safety knowledge emerged as the second theme. Data from the various instruments specifies that they were aware of the inherent danger on the roads. During the individual interviews many children expressed confidence in their knowledge of road safety skills as they saw themselves competent to go to school alone and to face the challenges on the roads.

I go to school alone because I am clever. (P1)

I come to school alone ... I know what to do. (P3)

I know the road. I know how to cross the road. (P4)

I am big enough to go to school alone. (P6)

I am clever; I have been taught about road safety. (P7)

The children expressed their self-reliance in using the road to school. Their sense of responsibility as pedestrians was expressed as the ability to walk to school alone unaccompanied by their parents. Their views on their responsibility were supported by our observations that no parents accompanied their children (aged between 10 and 14 years) to school. 
In addition, children expressed their knowledge of road use as follows:

I walk on the side of the road. (P1)

I use the small space next to the road. (P3)

I walk on the side of the road. I cross at the stop sign. I wait for cars to pass before I cross. (P4)

I do not play on the road. (P10)

From the interviews it was apparent that the majority of children reported on the inherent danger of walking in the middle of the road or playing on the road. What appears critical is that the child participants knew where the danger for pedestrians lay, for instance in the middle of the road.

Coupled with the concept of the danger of playing in the road is their acknowledgement that road safety is important in their lives as pedestrians and it should be taught. Children expressed their views as follows:

Yes - each child should know how to cross the and avoid being knocked down by cars. (P2)

Yes road safety is important because people do not take care. (P1)

Yes road safety education is important because most cars drink and knock down children. Children should be careful as well. (P3)

Yes road safety is important as some people do not know the road rules. (P4)

Yes many children are killed on the road. (P9)

Yes they must teach children to look for vehicles. (P10)

In an activity where the participants had to write road safety messages, one participant encapsulated his knowledge of the danger roads hold for children in this way:

Don't live [leave] children to play at the street. Because the car will bite them at the street is danger to send children to go at the roit [road] to go and buy something at the shop. (Verbatim)

This statement shows recognition that the roads are dangerous. This child is making a plea that parents should not send children to the shops alone as the child is well aware that this type of exposure on a road might cost children their lives. This statement is related to a real-life experience as one child, who was sent by parents to the shop, was killed by a car in the village during the time of the research project.

The only message for pedestrians that stood out from one child was 'wear bright clothes'. This is an important message in the sense that the child was aware or understood that if a pedestrian was using the road and wearing dark clothes, drivers would not see him/her. The concept of visibility on the road is critical for both pedestrians and drivers of vehicles.

In a group activity where children were required to draw a typical road environment with all the safety features, two children drew an informative picture of pedestrians on a pedestrian crossing. However, when they talked about their picture, their conversation about safety measures was directed at drivers, and not at pedestrians. Figure 1 shows their drawing. 


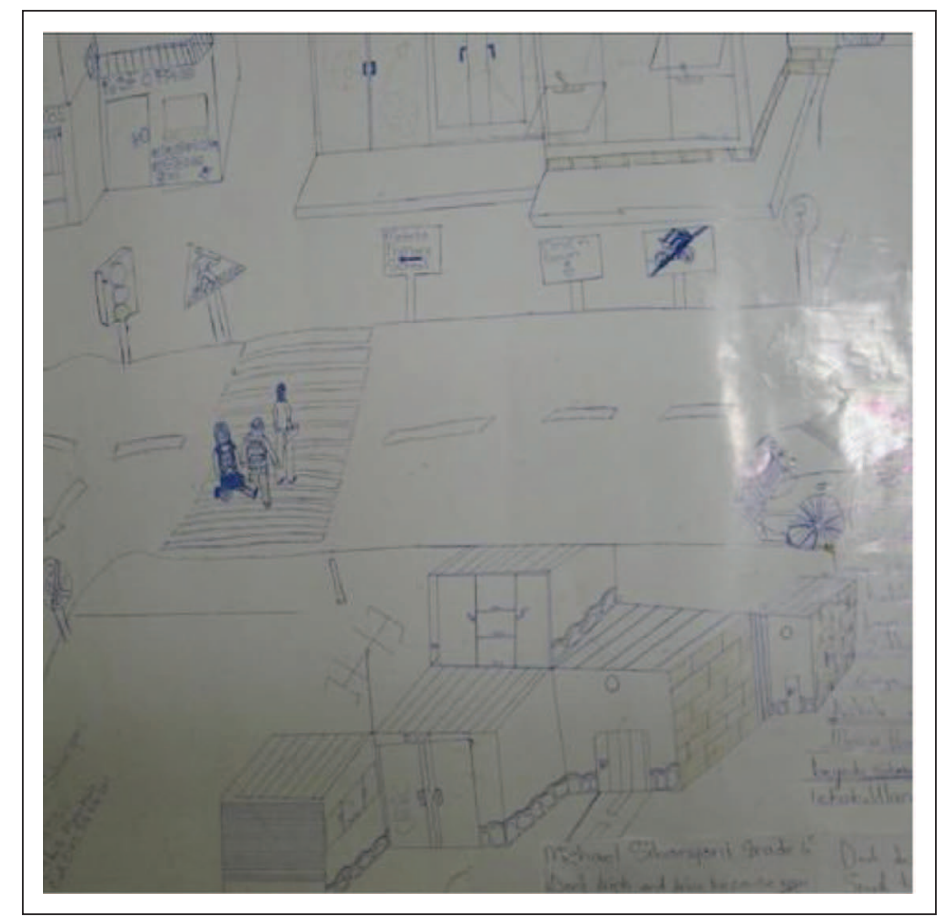

Figure I. Drawing of a typical road safety environment with road safety features by two children.

In Table 3 the responses of the two children about their drawing (Figure 1) when interviewed by the researchers, are provided.

One disturbing finding that emerged from this research project was the children's over-emphasis of the responsibility of drivers of vehicles to ensure safety on the roads. They did not acknowledge their own behaviour as pedestrians as a potential cause of accidents. In their thinking it seemed to be the fault of the driver of the vehicle if they were hit or involved in an accident. When comparing the children's road safety messages to drivers and to pedestrians in Table 4, it was evident that they shifted the responsibility to the drivers of vehicles as opposed to pedestrians.

From the messages to drivers of vehicles we noticed that drinking and driving, speeding and the lack of road signage featured prominently on the list of major causes of accidents in Moloto area, the site of the study. The following is a sample list of causes of accidents given by the child participants:

Drivers speak on cell phones. (P2)

People go to taverns before driving. (P3)

Lack of traffic police, people do not follow rules. (P4)

No road signs, people do not obey traffic rules. (P9)

People play on the road. (P10)

Children go to shops alone. (P2)

Moloto road has no robots. (P7) 
Table 3. Responses (verbatim) of child I and 2 about their drawing (Figure I).

Don't drink and drive because you are in ntrable Please don't drive more speed like speed 220

Arrive Alive

Follow rotes safe

And follow rotes traffic sign

And when you drive wear belt of car because belt will safe your life when you do an accident the belt of car will safe your life If you are a drink person don't even drive because you will surely die
Don't drink and drive:Arrive Alive Speed kills people Don't drive a speed of 280 Don't play on way if you are a child If you want to jump on the way please look at the robot when it say red You must stop a car and people jump roads

Table 4. Comparison of messages to drivers and pedestrians.

Messages for drivers of vehicles

'Do not drink more than two beers when using the road' (P7) - category: drinking and driving

'Slow down for your safety' (P6) - category: speeding

'Ensure your vehicle is road worthy'(P3) - category:

vehicle fitness

'Do not talk on the cell phone while driving' (P7)

- category: road safety violation

'Get rest every two hours' (P6) - category: fatigue
Messages for pedestrians

'Do not leave your child alone on the road' (P7) 'Do not cross the road when wearing black' (P7) 'Obey the signs that show you how to cross the road' (P4)

At their young age these participants were already cognisant of the behaviour of adults in terms of drinking before driving. This could be as a result of adult behaviour in their community or as a result of the Arrive Alive campaign in teaching road safety through its slogan in the mass media: 'Road Safety in South Africa is stay alive - Arrive Alive'.

The children were requested to draw an ideal Moloto road with road signs featured. What is especially important is that the road signs that appear on their drawing in Figure 2 were not on the Moloto road at the time of doing the study.

Across all themes the role of road signs in the prevention of accidents featured prominently. Almost all the children's drawings indicated the ideal Moloto road with all the features in the form of road signage which they hoped would reduce accidents. The evidence that the child participants had a clear understanding of what a safe route for pedestrians like them should be was significant for the study. They proposed that the Moloto road should have a four-way stop where pedestrians could cross safely. Another proposal was that it should have traffic lights to regulate the movement of both vehicles and pedestrians and all other road users.

We observed that, although children were taught the importance of road signs, of walking on pavements and crossing at the pedestrian crossing, the roads were designed for cars. There were no pavements in the entire Moloto Village, and only one pedestrian crossing far from the school. Children or any other pedestrians would not walk a distance to cross at a relatively safe spot. 


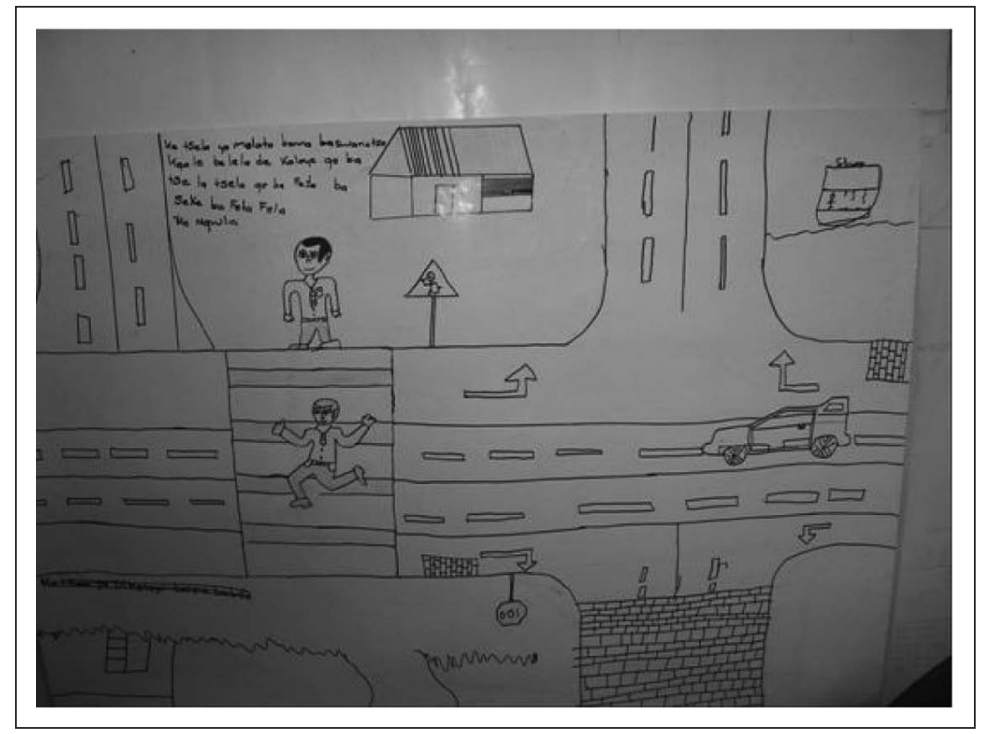

Figure 2. Drawing of an ideal Moloto Road with road signs.

They would rather take chances and cross where they were not supposed to cross. It is common knowledge that, in South Africa, most road infrastructures are designed for vehicles and not for pedestrians. Pedestrians are supposed to fit into the design, which in the end is not pedestrianfriendly. This is the reason why pedestrian facilities are mostly added after the completion of the building of the road; in most cases only when the community exerts pressure after a number of pedestrian fatalities.

\section{Attitudes to Road Safety and their Value of Life}

The participant children's attitudes to road safety and their value of life emerged as the third theme. The individual interviews and the children's written road safety messages revealed the children's positive attitude to road safety. The child respondents were very much concerned about road safety, as the following responses and comments indicate:

Message no. 3 (P10; verbatim)

Road save:

When you are in the road you must be careful.

When you are in a car you must be sure that you now [know] the sign of the road.

When you to cross the road-you must look at the right hand and left hand.

You must not play in the road some of the car they will couse [cause] a problem to you.

You must go with some one! When you afrait [afraid]. 
The messages were expressions of safety actions like 'be careful', 'be sure that you now [know] the sign' and 'not play in the road'.

A value that emerged from the road safety messages was the children's understanding of the importance of family values and the value of life. The following messages are enlightening in this regard:

When you drive think about your family. (P3)

Drive carefully, do not kill your family, yourself. You will cry forever. (P3)

The concern of this child participant was that a driver who is reckless will kill his family, and if he survives the accident he will regret his actions for ever. This indicates this child's appreciation of life.

\section{Influence of Unsafe Road Environments}

Children being influenced by an unsafe road environment emerged as the fourth theme. The positive attitude of the children is contradicted by what we learned as the unsafe culture of road use which permeates the community of Moloto Village where the primary school is situated. The photos taken as a 'photo voice' data collection instrument revealed the contradiction between the children's enthusiasm and positive attitude to road safety and their actual road use behaviour. The photos showed children crossing the road recklessly. They were violating the basic rule of crossing the road, look right, look left and look right again before crossing. They were seen crossing in a file, crossing where there is no pedestrian crossing. Not even the presence of a police vehicle deterred them from this unsafe pedestrian behaviour. Figure 3 and Figure 4 illustrate instances of the unsafe pedestrian behaviour observed in Moloto Village during the study.

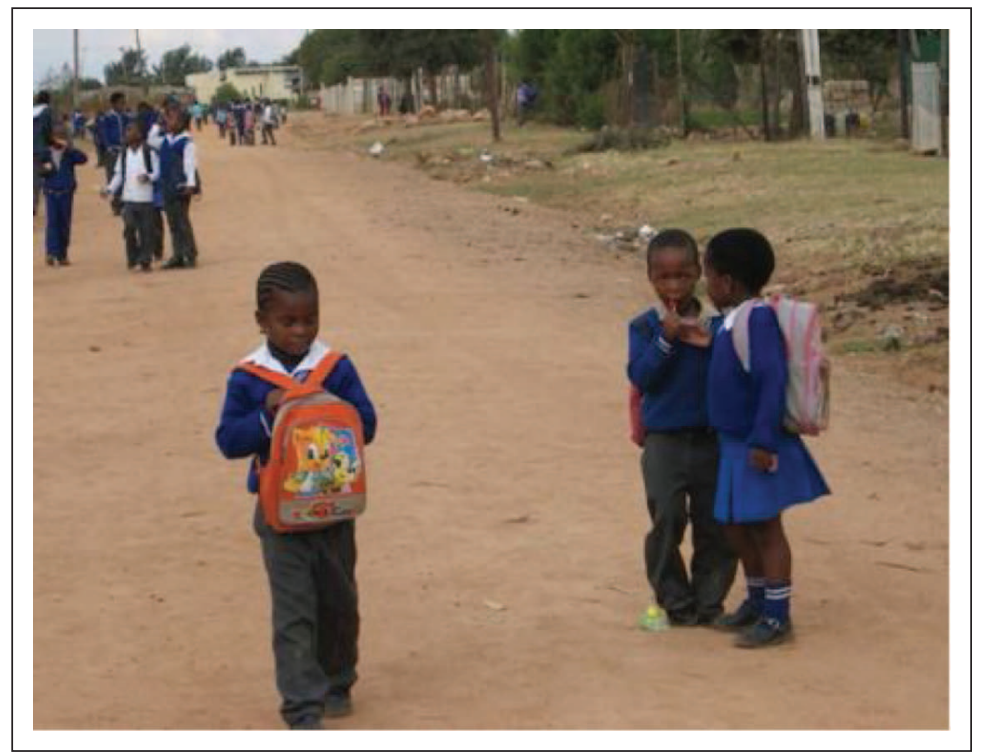

Figure 3. Children coming home from school and walking in the middle of the road. 


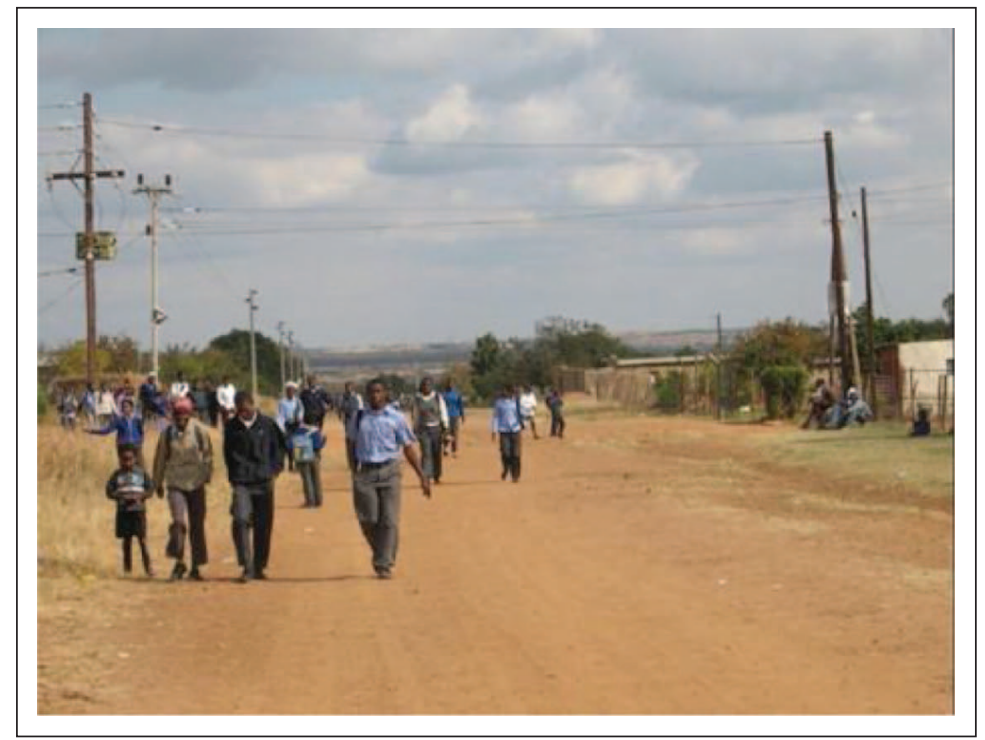

Figure 4. Children going to school and walking in the middle of the road.

The photos portray dangerous road behaviour by the children and adults of the community. The unsafe road use behaviour of child pedestrians in particular supported our insight that the child participants regarded road safety as the responsibility of drivers of vehicles to ensure that they did not hit pedestrians. The following characteristics of pedestrian behaviour were observed in the photos:

- Children were crossing the road away from pedestrian crossings; they were crossing everywhere.

- Children knew what they should do before crossing a busy road like the Moloto road, but they did not put their knowledge into practice.

- They walked in the middle of the road as everybody did, especially in the arterial road into Moloto road, the main road in the village. They expected vehicles to yield for them.

- They crossed the road in a file.

The child participants, although they knew the correct pedestrian skills, did what other community members were doing. The photos illustrate adults setting a negative example regarding road safety skills. The adult community members were observed using the road in an unsafe way alongside the children. They were even crossing the road at a very dangerous part of the road with no pedestrian crossing. We posit that this unsafe community behaviour undermined the theoretical input that the children expressed they had learnt at school.

\section{Discussion}

The findings of this study revealed the child participants' responses on two levels, namely on the theoretical and the practical level. On the theoretical level, the children revealed a reasonable understanding of road safety. This cognition relates well with the competencies stated by the GRSP (2001).Their responses indicated that they understood and appreciated the role that road signs 
played in ensuring that the roads were safe for pedestrians, as illustrated by the drawings of an ideal, safe Moloto road. They proposed the use of road signs to improve the safe movement of learners when crossing the Moloto road. In addition, they recommended robots, pedestrian crossings, and stop signs, and signs prohibiting pedestrians from crossing the road anywhere.

On the practical level, we observed the child participants behaving in an unsafe manner on the Moloto road. This culture could be deadly in an environment where most of the children are pedestrians. It seemed that there was no correspondence between what these children knew about pedestrian safety and what they did in practice. An explanation for this anomaly is that the community as a whole used the road in an unsafe way. As a result, these children had observed and internalized this unsafe behaviour, which emphasizes the acknowledged weakness of the behaviourist theory.

Another explanation for this inconsistency could relate to these children's developmental levels. The findings from our research project show that the children did not behave according to their proclaimed road safety knowledge, indicating their immaturity. However, as they grow and develop physically and cognitively, children take more responsibility for own actions (Biehler and Hudson, 1986: 324-326; Hetherington and Parke, 1993: 315-338; Peden et al., 2004). According to Research Report 9 of the Department for Transport (2007), the 'older child becomes more aware of the causes of an accident, and the role his or her behaviour might play in precipitating an accident, responsibilities on the road are re-conceptualized in a new way: "good" behaviour on the roads becomes a matter of avoiding the behaviours (errors) which might lead to an accident'. A last possible reason for this contradiction between theory and practice is an inadequate curriculum with no holistic approach to road safety.

Regardless, the children's attitudes to road safety in our case study emerged as positive as they expressed an awareness of the danger of using the road infrastructure in a reckless way. The central argument is that road safety is important; they said 'a bahlokomelemo di tseleng' (most people are not careful on the road), indicating that those who are careless on the road get killed. Having this positive attitude, children in rural environments will hopefully mature, construct their own road safety knowledge and act responsibly, even though the community's behaviour is unsafe.

The problem has to be approached from two levels, namely the national and the local level. First, from the political perspective, human rights and social justice should prevail. Although the state guarantees safety for all its citizens, the poor are unable to access these rights as their socioeconomic status works against them (Nantalya and Reich, 2003; Ndungane, 2006, 2010; Ramphele, 2006). The pedestrian infrastructure should form part of the road infrastructure from conception, and not only be implemented as an afterthought when the road has been completed. Policy makers should ensure that road safety is prioritized if South Africa is to meet the millennium development goal of halving deaths on the road by 2014 (Department for Transport, 2006). Policy makers have to legislate the working relationships between the departments of Health, Transport, Justice and Constitutional Development and Education. This working relationship should be coordinated by a facilitating agency like the Road Traffic Management Corporation (RTMC, 2005).

Second, key stakeholders have to be motivated to support and make inputs into road safety intervention measures that are to be implemented in their communities. This will increase accountability, acceptability and ownership of intervention measures by the affected communities. It is against this background that the study consciously used participatory methods to give children as pedestrians the opportunity to design measures that they thought would make the Moloto road safer for them as pedestrians. Our belief is that road safety interventions have to be designed in accordance with the local socio-economic and political contexts and dynamics (see also Maurice, 2007). This has to be guided by research involving the community who are the affected population. Such efforts will provide a realistic and holistic picture as a base for intervention measures. 


\section{Conclusions}

Road safety education can be summarized as a process with sequenced and structured goals, mainly the provision of information about injury risks and how to avoid them, changing attitudes towards risk and safety and altering behaviour. Educating young children should be holistic, and their construction of road safety knowledge and pedestrian skills facilitated in a simulated road environment. Education has to move beyond the school environment to all stakeholders in the community such as community leaders who have a role to play in reinforcing messages received through formal education. Encouraging safety practice may help to develop ownership of the problem and engender a safety awareness culture. The findings from this study will hopefully create a culture of safe road use on the Moloto road and may have indicators for other campaigns aimed at modifying behaviour such as drug and alcohol abuse, smoking and practicing unsafe sex.

\section{References}

Accra Declaration Ministerial Round Table (2007) African road safety conference Accra, Ghana, 8th February 2007. African Safety Promotion: A Journal of Injury and Violence Prevention, 5(1): 117-119.

Adendorff DE (2004) An Investigation into the Roles and Competencies of an Online Facilitator. $\mathrm{PhD}$ thesis, University of Pretoria, South Africa.

Benjamin KB and Schwebel DC (2007) The roles of age, gender, inhibitory control, and parental supervision in children's pedestrian safety. Journal of Pediatric Psychology, 32(5): 517-526.

Bergin CC and Bergin DA (2012) Child and Adolescent Development in Your Classroom. Australia: Wadsworth Cengage learning.

Biehler RF and Hudson LM (1986) Development Psychology: An Introduction, 3rd edition. Boston, MA: Houghton Mifflin Company.

Braun V and Clarke V (2006) Using Thematic Analysis in Psychology, Volume 3. Edward Arnold Publishers. Bristol, University of the West of England. Available at: http://dx.doi.org/10.1191/1478088706gp06e3oa.

Campbell RL (1997) Jean Piaget's Genetic Epistemology: Appreciation and Critique. A revised version of two lectures presented at the Institute of Objectivist Studies Summer Seminar, Charlottesville, VA, 7-8 July.

Cape Argus (2004) 29 September.

Cape Times (2004) 28 September.

Charmaz K (2000) Grounded theory: Objectivist and constructivist methods. In:Denzin NK and Lincoln YS (eds) Handbook of Qualitative Research, 2nd edition. London: Sage.

Child Development (2009) Learning Theories Knowledgebase. Constructivism at Learning-Theories.com. Available at: http://www.learning-theories.com/constructivism.html (accessed 7 September 2009).

Christie N, Cairns S, Towner E and Ward H (2004) Children's Road Traffic Safety: An International Survey of Policy and Practice. Road Safety Research Report No. 47. London: DfT.

Commission for Global Road Safety: FIA Foundation (2006) Make Roads Safe. Available at: http://www. makeroadssafe.org/ (accessed 22 June 2006).

Davis A and Quimby A (2003) Promoting road safety in developing countries through community education programmes: Literature review. Transport Research Laboratory, Project Report PR/INT/261/03. London, Department for International Development.

Danish Road Safety Commission (2000) Every Accident is One Too Many, Road Safety Starts with You: Towards New Objectives 2001-2012. Danish Ministry of Transport.

Denzin NK and Lincoln YS (eds) (2000) Handbook of Qualitative Research, 2nd edition. London: Sage.

Department for Transport (2006) Research Report No. 6: Cognitive and Metacognitive Processes: Underlying the Development of Children's Pedestrian Skills. Available at: http:/wwwdft.gov.uk/stellent/groups/dft_ Department for Transport (2007) Child Road Safety Strategy. London: DfT.

Department of Education (2002) Revised National Curriculum Statement. Grades R-9 (Schools) Policy. Pretoria: Department of Education. 
Department of Transport (2001) The Road to Safety 2001-2005. Pretoria: Government Printers.

Department for Transport (2007) Child Road Safety strategy, Research report No. 09. London, Transport Research Laboratory.

Department of Transportation (US) (2004) A Review of Pedestrian Safety Research in the United States and Abroad. Publication No. FHWA-RD-03-042. Research Development and Technology. Mclean: Turner-Fairbank Highway Research Center.

Eggen P and Kauchak D (2001) Educational Psychology: Windows on Classroom, 5th edition. New Jersey: Merrill Prentice Hall, Upper Saddle River.

Forjuoh SN (2003) Traffic-related injury prevention interventions for low-income countries. Injury Control and Safety Promotion, 10(1-2): 109-118.

Global Road Safety Partnership (GRSP) (2001) Road Safety Education in Schools: Saving Young Lives and Limbs. Geneva, Switzerland, Global Road Safety Partnership.

Global Road Safety Partnership (GRSP) (2003) Annual Report, June 2003. Geneva, Switzerland, Global Road Safety Partnership.

Glover JA and Bruning RH (1990) Educational Psychology: Principles and Applications, 3rd edition. Scott, Foresman and Company.

Guldbrandsson K and Bremberg S (2004) A study of safety-promoting activities for children and adolescents in 25 Swedish municipalities. Health Promotion International, 19(2): 215-225.

Herald Reporter (2004). Apartheid (Dumps) one reason for pedestrian deaths. 11 April, 2004.

Hetherington EM and Parke RD (1993) Child Development - A Contemporary Viewpoint, 4th edition. New York: McGraw-Hill.

Hunt J (1969) The impact and limitations of the giant of developmental psychology. In Elkind D and Flavell J (eds) Studies in Cognitive Development: Essays in Honor of Jean Piaget. New York: Oxford University Press.

Hurlock EB (1981) Child Development. Tokyo: McGraw-Hill.

Jacobs G and Aeron-Thomas A (2000) Estimating global road fatalities. Transport Research Laboratory Report 445. Africa Road Safety Review Final Report; PR/INT/659/2000. TRL Limited, 2000. US Department of Transportation/Federal Highway Transportation.

Leedy PH and Ormrod JE (2001) Practical Research: Planning and Design, 7th edition. New Jersey: Prentice-Hall.

Matipa P (2012) Meeste bots as maandeindig [Most accidents occur at the end of the month]. Beeld, 13 March, p. 7.

Maurice P (2007) Influences of civil society and social movements: Comments on Svanstrom, Saloojee and Kirsten. African Safety Promotion: A Journal of Injury and Violence Prevention, 5(1).

May T (1997) Social Research. Issues, Methods and Process, 2nd edition. London: Open University Press. Mayer RE (1987) Educational Psychology: A Cognitive Approach. California, Harper Collins Publishers.

McComas J, MacKay M and Pivik J (2002) Effectiveness of virtual reality for teaching pedestrian safety. Cyber Psychology \& Behaviour, 5(3). Mary Ann Liebert, Inc.

McMillan JH and Schumacher S (2002) Research in Education: A Conceptual Introduction, 5th edition. New York, USA, Addison Wesley Longman, Inc.

Merriam SB (1998) Qualitative Research and Case Study Applications in Education: Revised and Expanded from Case Study Research in Education. San Francisco, CA: Jossey-Bass Publishers.

Mohan D (2003) People's right to safety. Health and Human Rights, 6(2): 161-167.

Monson J, Hall K, Smith C and Shung-King M (2006) South African Child Gauge 2006. Cape Town: Children's Institute, University of Cape Town.

Muhlrad N (1998) Integrated road safety management: Inter-sectoral policies and institutional organisation. In: Mohan D and Muhlrad N (eds) Introduction to Road Traffic Safety: A Multidisciplinary Approach, pp. 128-138. International Course on Prevention and Control of Traffic Accidents and Injuries. New Delhi, 7-15 December, Indian Institute of Technology.

Muhlrad N and Wittink R (1998) Road safety management: From the national to the local level. In: Mohan D and Muhlrad N (eds) Introduction to Road Traffic Safety: A Multidisciplinary Approach, pp. 246-256. 
International Course on Prevention and Control of Traffic Accidents and Injuries. New Delhi, 7-15

December, Indian Institute of Technology.

Nantalya VM and Reich MR (2003) Equity dimensions of road traffic injuries in low-and middle-income countries. Control Safe Promotion, 10(1-2): 11-14.

National Department of Transport (2006) Strategic Plan 2006-2009. Pretoria.

Ndungane WHN (2006) Reflections on children and poverty. In: Monson J, Hall Smith K and Shung-King M

(eds) South African Child Gauge. Cape Town: Children's Institute, University of Cape Town.

Ndungane WHN (2010) Education: The 'horseshoe nail' of a nation. The Thinker, 13: 46-48.

Odero W (2004) Africa's Epidemic of Road Traffic Injuries: Trends, Risk Factors and Strategies for Improvement. A paper presented at the Harvard Center for Population and Development Studies on the Occasion of the World Health Day, 9 April 2004.

Olivier T, Wood L and De Lange N (2009) 'Changing our eyes': Seeing hope. In:de Lange N, Mitchel C and Stuart J (eds) Putting People in the Picture. Visual Methodologies for Social Change. Rotterdam: Sense Publishers.

Peden M, Scurfiel R, Sleet D, Mohan D and Hyder AA (2004) World Report on Road Traffic Injury Prevention. Geneva: World Health Organization.

Presidency (2001) Children in 2001: A report on the Nation's Children. Pretoria, The Presidency of the Republic of South Africa.

Ramphele M (2006) Securing safety as a right: From knowing to doing. African Safety Promotion: A Journal of Injury and Violence Prevention, 4(1): 22-28.

Republic of South Africa (1996) The constitution of the Republic of South Africa, 1996. Act No. 108 of 1996. Government Gazette, 378(17678): 18 December. Cape Town: Government Printer.

Ribbens H (2002) Strategies to promote the safety of vulnerable road users in developing and emerging countries: The South African experience. CSIR Transportek, TRB Annual meeting, Unpublished conference paper.

Road Safe (2006) Make roads safe. Roadsafe Magazine, Winter 2006/2007.

Road Safety Manual (2003) PIARC Technical Committee on Road Safety (C13). Permanent International Association of Road Congresses (PIARC), World Road Association.

Road Traffic Management Corporation (RTMC) (2005) Road Traffic and Fatal Crash Statistics 2003-2004.

Pretoria, The Road Transport Management Corporation.

Robinson C and Kellet M (2004) Power. In:Fraser S, Lewis V, Ding S, Kellet M and Robinson C (eds) Doing Research with Children and Young People. London: Open University Press.

Ryhammar L (1998) Traffic safety education in the compulsory school: A problem. Journal of Traffic Safety Education, XXXV (3): 121. Uppsalla Universitet, National Academy of Sciences. Available at: http:// worldcat.org/isbn/91867440406.

Schunk DH (1991) Learning Theories: An Educational Perspective. New York: Macmillan.

Schunk DH (2012) Learning Theories: An Educational Perspective. Boston, MA: Pearson.

Seale C (1999) The Quality of Qualitative Research. London: Sage.

Slavin RE (2002) Educational Psychology: Theory and Practice (6th edition). Boston, MA: Allyn and Bacon.

Sukhai A (2003) Epidemiology of Road Traffic Injury in South Africa: An Overview. Presentation made during the Injury Control and Traffic Safety Workshop held at the SA Technikon Conference Centre in Johannesburg, 21-25 July.

Thomson JA, Tolmie A, Foot HC and McLaren B (1996) Child Development and the Aims of Road Safety Education: A Review and Analysis. Department of Transport. Road Safety Research Report No. 1. Norwich: HMSO.

United Nations (1989) Convention on the Rights of the Child. New York.

Wittink R (1998) Road safety education. In:Mohan D and Muhlrad N (eds) Introduction to Road Traffic Safety: A Multidisciplinary Approach, pp. 125-127. International Course on Prevention and Control of Traffic Accidents and Injuries. New Delhi, 7-15 December.

World Bank Group (2002) Road Safety. Available at: http://www.worldbank.org/html/transport/roads/safety. htm (accessed 10 November 2004). 
World Health Organization (2004) The World Report on Road Traffic Injury Prevention, Peden M. et al. (eds). Geneva, Switzerland.

Zeedyk MS, Wallace L, Carcary B, Jones K and Larter K (2001) Children and road safety: Increasing knowledge does not improve behaviour. British Journal of Educational Psychology, 71: 573-594.

\section{Author biographies}

Ina JC Joubert is senior lecturer in the Department Early Childhood Education, Faculty of Education, University of Pretoria. She specializes in citizenship and matters that affects young children's safety.

William J Fraser is Professor in the Department of Science, Mathematics and Science Education, Faculty of Education, University of Pretoria. He specializes in curriculum development (curriculum theory and practice), instructional design and development, the methodology of biology teaching, testing, measurement, assessment and quality assurance. He is a charted biologist, Fellow of the Society of Biology and member of the South African Academy for Science and Arts.

Mpoye L Sentsho is a Manager for Road Safety Education in the North West Province, South Africa, based in Rustenburg. His special interest is in the provision of road safety education to children of school going age. 